\title{
Titanium Recycling in the United States in 2004
}

\author{
By Thomas G. Goonan
}

\section{U.S. GEOLOGICAL SURVEY CIRCULAR 1196-Y}




\section{U.S. Department of the Interior \\ KEN SALAZAR, Secretary \\ U.S. Geological Survey \\ Marcia K. McNutt, Director}

U.S. Geological Survey, Reston, Virginia: 2010

For product and ordering information:

World Wide Web: http://Www.usgs.gov/pubprod

Telephone: 1-888-ASK-USGS

For more information on the USGS - the Federal source for science about the Earth, its natural and living resources, natural hazards, and the environment:

World Wide Web: http://www.usgs.gov

Telephone: 1-888-ASK-USGS

Any use of trade, product, or firm names is for descriptive purposes only and does not imply endorsement by the U.S. Government.

Although this report is in the public domain, permission must be secured from the individual copyright owners to reproduce any copyrighted materials contained within this report. 


\section{FOREWORD}

As world population increases and the world economy expands, so does the demand for natural resources. An accurate assessment of the Nation's mineral resources must include not only the resources available in the ground but also those that become available through recycling. Supplying this information to decisionmakers is an essential part of the USGS commitment to providing the science that society needs to meet natural resource and environmental challenges.

The U.S. Geological Survey is authorized by Congress to collect, analyze, and disseminate data on the domestic and international supply of and demand for minerals essential to the U.S. economy and national security. This information on mineral occurrence, production, use, and recycling helps policymakers manage resources wisely.

USGS Circular 1196, "Flow Studies for Recycling Metal Commodities in the United States," presents the results of flow studies for recycling 26 metal commodities, from aluminum to zinc. These metals are a key component of the U.S. economy. Overall, recycling accounts for more than half of the U.S. metal supply by weight and roughly 40 percent by value.

Marcia K. McNutt

Director 


\section{CONTENTS}

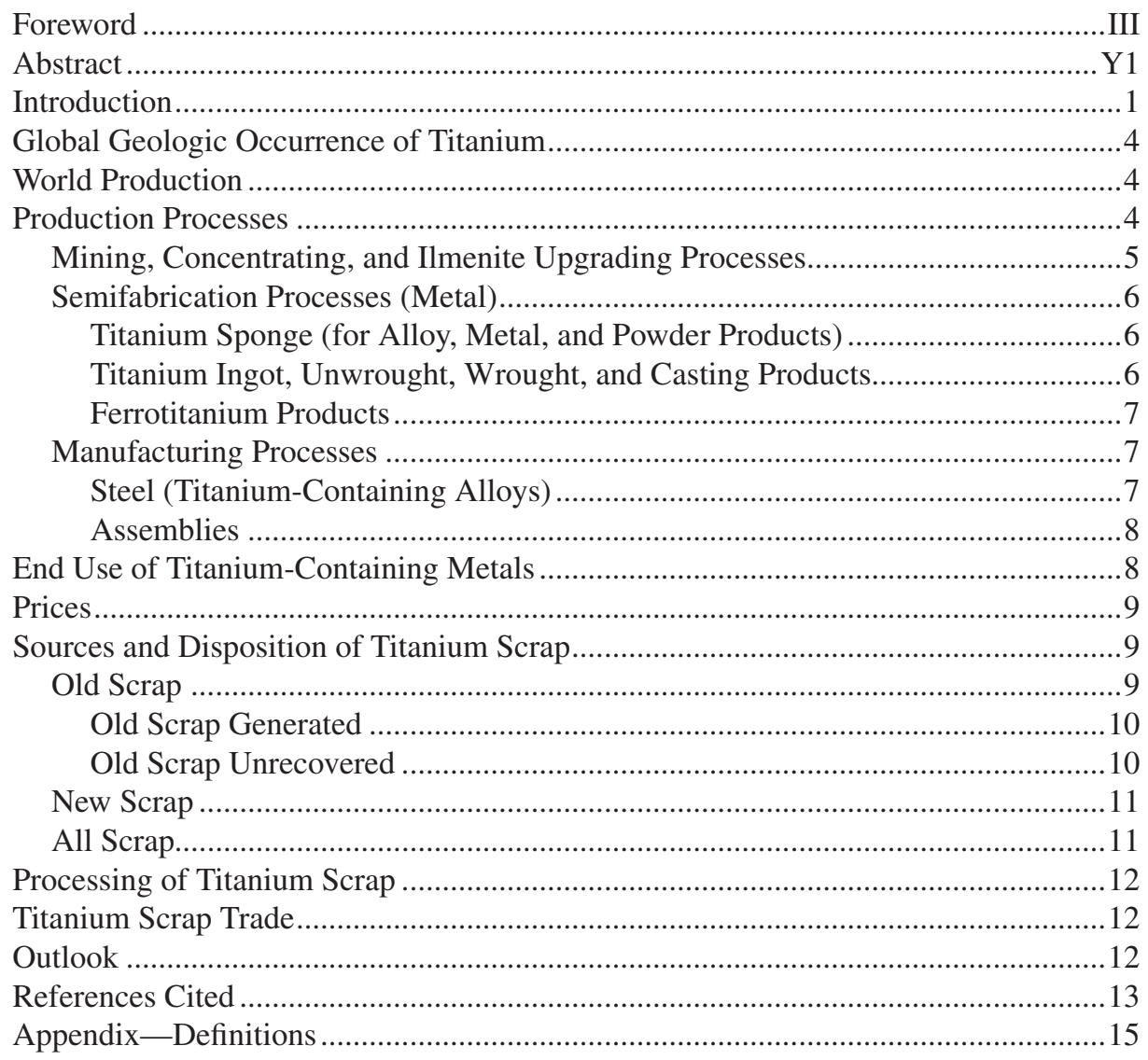




\section{FIGURES}

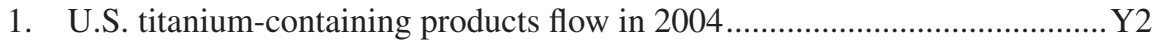

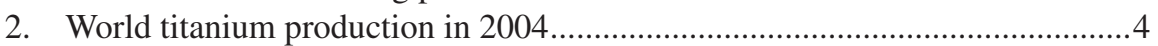

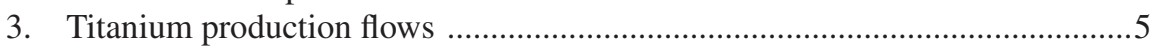

4. Titanium sponge production through Kroll process .......................................

5. Ferrotitanium production ...........................................................................

6. Consumption of gross titanium alloys by the U.S. steel industry ..................... 8

7. U.S. apparent titanium sponge and scrap consumption ..................................

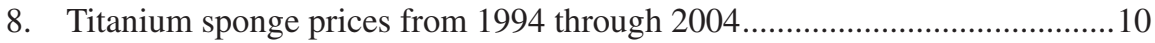

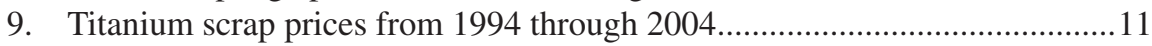

10. Sources of U.S. titanium scrap imports in $2004 \ldots \ldots \ldots \ldots \ldots \ldots \ldots \ldots \ldots \ldots \ldots \ldots \ldots \ldots \ldots \ldots . . .12$

11. Titanium scrap and sponge consumption and ingot production from 1972

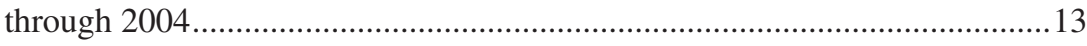

\section{TABLE}

1. Salient statistics for titanium flow in the United States in 2004 ................... Y3 


\section{CONVERSION FACTORS}

\begin{tabular}{ccc}
\hline Multiply & By & To obtain \\
\hline gram $(\mathrm{g})$ & 0.03527 & \\
kilogram $(\mathrm{kg})$ & 2.205 & ounce avoirdupois $(\mathrm{oz})$ \\
metric ton $(\mathrm{t}, 1,000 \mathrm{~kg})$ & 1.102 & pound avoirdupois $(\mathrm{lb})$ \\
short ton $(2,000$ pounds $)$
\end{tabular}




\title{
FLOW STUDIES FOR RECYCLING METAL COMMODITIES IN THE UNITED STATES
}

\section{Titanium Recycling in the United States in 2004}

\author{
By Thomas G. Goonan
}

\begin{abstract}
As one of a series of reports that describe the recycling of metal commodities in the United States, this report discusses the titanium metal fraction of the titanium economy, which generates and uses titanium metal scrap in its operations. Data for 2004 were selected to demonstrate the titanium flows associated with these operations. This report includes a description of titanium metal supply and demand in the United States to illustrate the extent of titanium recycling and to identify recycling trends.

In 2004, U.S. apparent consumption of titanium metal (contained in various titanium-bearing products) was 45,000 metric tons ( $\mathrm{t}$ ) of titanium, which was distributed as follows: $25,000 \mathrm{t}$ of titanium recovered as new scrap, 9,000 $\mathrm{t}$ of titanium as titanium metal and titanium alloy products delivered to the U.S. titanium products reservoir, 7,000 t of titanium consumed by steelmaking and other industries, and 4,000 t of titanium contained in unwrought and wrought products exported. Titanium recycling is concentrated within the titanium metals sector of the total titanium market. The titanium market is otherwise dominated by pigment (titanium oxide) products, which generate dissipative losses instead of recyclable scrap. In 2004, scrap (predominantly new scrap) was the source of roughly 54 percent of the titanium metal content of U.S.produced titanium metal products (fig. 1).
\end{abstract}

\section{INTRODUCTION}

Titanium mineral concentrates are the product of titanium mining and beneficiation and provide the raw material for the two most important types of product that the titanium industry produces - titanium oxides for pigment applications (in paint, paper, plastic and other) and titanium metal and alloys for cast and wrought product applications largely in aerospace (airframes, engines, and landing gear) and, to a lesser degree, in developing applications (such as medical implants, process tanks, roofing, and substitution for stainless steel). Titanium is also used in industries unrelated to pigment or metal-for example, for welding rod coatings, heavy media separation processes, and a variety of titanium-based chemicals. Titaniumbased catalysts are used in olefin polymerization.
In 2004, 98 percent of the titanium contained in the U.S. titanium mineral concentrate supply progressed through the pigment sector of the titanium market. The remaining 2 percent flowed to miscellaneous other uses, including the metal sector. Since all titanium scrap is generated and recycled (the primary subject of this report) within the titanium metal market sector, the flows of titanium through the pigment sector are not reported here.

This study provides a snapshot (fig. 1) of the flow through the U.S. economy of recoverable titanium metal (contained in various titanium-containing metal forms) in 2004 and identifies sources of U.S. titanium metal supply and distribution with particular emphasis on the flow ${ }^{1}$ of titanium contained in scrap.

The useful semifabricated titanium metals products that manufacturers need are wrought shapes and castings that contain the appropriate chemical analysis (alloy content). The steel industry is also a consumer of titanium, usually in the form of ferrotitanium, scrap, and sponge. In 2004, the U.S. steel and other industries together consumed about 7,000 metric tons (t) of titanium contained in titanium-bearing metal products (17 percent of estimated U.S. titanium metal consumption).

The supply of wrought and cast metal is generated through process steps that convert titanium concentrate into titanium metal sponge, which may or may not be subsequently combined with titanium scrap and master alloys of other elements (when required) to generate titanium and (or) titanium-alloy ingot products that can be shaped to the needs of the customer.

In 2004, titanium ingot makers consumed sponge titanium and titanium contained in purchased and other [in-house and (or) downstream] scrap returns. In 2004, the ratio of sponge consumption to scrap consumption in the United States was 0.95 . The ratio of sponge to scrap for ingot production was about 1.47. With adjustment to the 37,000 $\mathrm{t}$ of ingot produced for net imports containing $1,000 \mathrm{t}$ of titanium and a net stock decrease of ingot containing 1,000 $\mathrm{t}$ of titanium, 38,000 $\mathrm{t}$ of titanium entered semifabrication (castings and wrought and unwrought shapes). Semifabricators distributed products

${ }^{1}$ As a general rule, flow information (numbers associated with arrows in the diagrams) is derived from disparate data sources with differing levels of quality and is not as precise as the reporting indicates. One should view the reported values relative to each other, rather than for the precision of the data. 

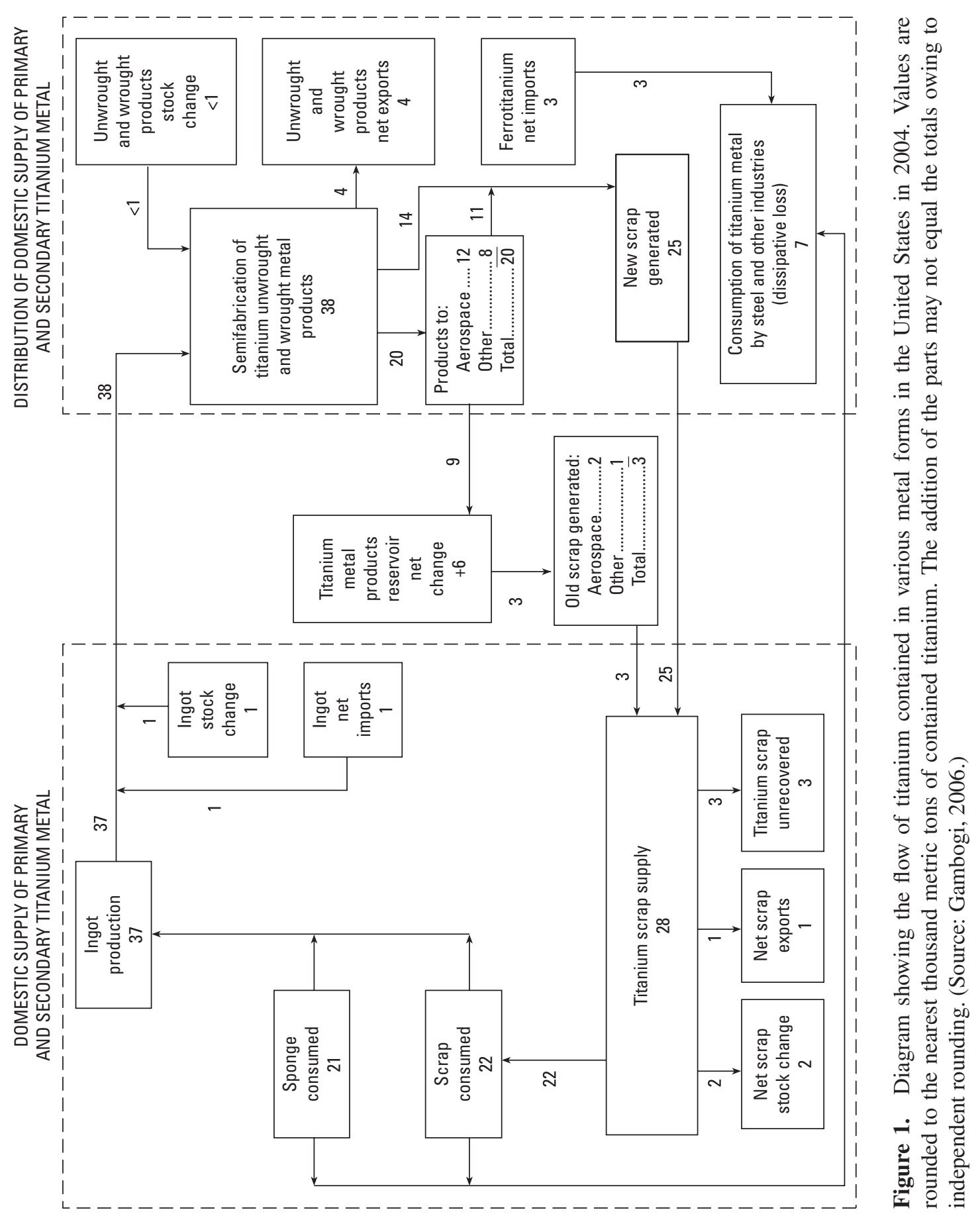
containing 24,000 t of titanium (20,000 t to U.S. aerospace and other industries and 4,000 t to exports) and generated new scrap containing 14,000 t of titanium. The manufacturers that received the semifabricated products that contained $20,000 \mathrm{t}$ of titanium produced products for the U.S. titanium product reservoir, which contained 9,000 t of titanium, and generated an additional quantity of scrap containing about 11,000 t of titanium. The total new scrap generated from semifabrication and further manufacturing contained 25,000 t of titanium, which flowed to the U.S. titanium scrap supply.

About 3,000 t of titanium contained in old scrap became available in 2004 from the obsolescence of product assemblies, of which 2,000 $\mathrm{t}$ was generated by the aerospace industry and 1,000 t was generated by others (Joseph Gambogi, U.S. Geological Survey, written commun., May 13, 2009). There is little reporting on the use of old scrap in titanium recycling. New scrap is preferred for use and trade because the quality is controllable (Suisman and Wasserman, 1989). This generates a tendency for old scrap to hibernate (to remain in place or to be stockpiled). High-quality purchased and internally generated scrap tends to flow to ingot production. Lower quality scrap and some indeterminate amount of old scrap tend to flow to ferrotitanium production, which is essentially a clean-blend-and-melt operation that combines titanium scrap and iron scrap.

The amount of titanium contained in imported product assemblies that embody airframes, turbine blades, and other metal applications is not known. The titanium metals product reservoir theoretically (estimate details discussed below) generated 35,000 t of titanium as old scrap. However, without reported information about old scrap flow, it was not possible to estimate the fraction that was recovered and unrecovered. Likewise, it was not possible to estimate the old scrap recycling efficiency, recycling rate, or the new-scrap to old-scrap consumption ratio for U.S. titanium product production. Salient titanium flow statistics for 2004 are summarized in table 1.

Because there are no data regarding the proportion of old scrap and new scrap, and production data for sponge and ferrotitanium are withheld to avoid disclosing company proprietary data, the statistics provided in table 1 are not comparable with those for other commodities in Circular 1196. The statistics in table 1 reflect what happened in 2004 with respect to all scrap, old and new taken together, and are consistent with the definitions put forth in the appendix of this report.

In 2004, 22,000 t of titanium contained in all scrap was consumed by U.S. titanium metal producers.

There are some generalizations that can be made about titanium scrap handling, as follows:

1. Recycling of new and home titanium scrap is robust and largely complete.

2. Demand for titanium products and supply of old scrap have both been growing.

The obstacles to using old scrap to fulfill greater general demand for titanium-containing alloys are quality related. Future research by alloy makers and scrap processors was expected to be directed to overcoming these obstacles.

Table 1. Salient titanium metal flow statistics for the United States in 2004.

[Values are in thousand metric tons of contained titanium, unless otherwise specified]

\begin{tabular}{|c|c|}
\hline \multicolumn{2}{|l|}{ 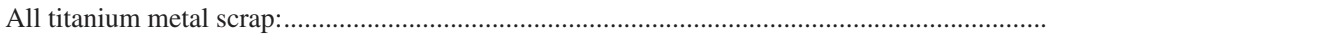 } \\
\hline 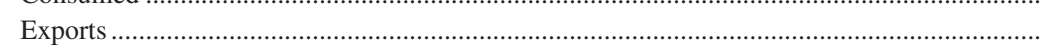 & 10 \\
\hline Export value ................... & $\$ 56$ million \\
\hline Imports .. & 9 \\
\hline Import value. & \$54 million \\
\hline Generated ................... & 28 \\
\hline Old scrap, theoretical... & 3 \\
\hline New scrap. & 25 \\
\hline Ratio of new to old scrap consumed & Greater than 7 \\
\hline Recycling efficiency, as percent of all scrap supply & 91 percent \\
\hline 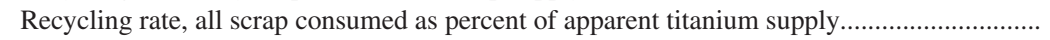 & 52 percent \\
\hline 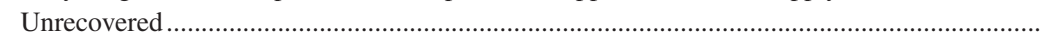 & 3 \\
\hline \multicolumn{2}{|l|}{ Titanium metal:... } \\
\hline \multicolumn{2}{|l|}{ Apparent consumption: } \\
\hline By semifabricators of wrought and unwrought products & 38 \\
\hline By steelmaking and other industries & 7 \\
\hline Total & 45 \\
\hline 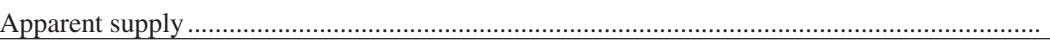 & 42 \\
\hline
\end{tabular}




\section{GLOBAL GEOLOGIC OCCURRENCE OF TITANIUM}

Titanium is one of the transition elements in group IVB of the periodic table, along with zirconium and hafnium. Titanium has a strong affinity for oxygen, forms oxides and oxysalts, and has no tendency to concentrate in metallic iron or to form sulfides. The principal titanium minerals form primarily as products of the crystallization of igneous magmas and as recrystallization products in metamorphic rocks. Rutile deposits occur as local concentrations in igneous and metamorphic rocks, in veins associated with igneous and metamorphic rocks, and as concentrations in sedimentary rocks and unconsolidated sediments derived from weathering of rutile-bearing rocks (Klemic and others, 1973).

Titanium tends to be incorporated in three common titanium minerals-ilmenite $\left(\mathrm{FeTiO}_{3}\right)$, rutile $\left(\mathrm{TiO}_{2}\right)$, and sphene $\left(\mathrm{CaTiSiO}_{5}\right)$. Ilmenite accounts for more than 90 percent of the titanium-bearing constituents of igneous rocks. The greatest abundance of titanium is in rocks that contain less than 52 percent silica, including iron silicates, magnesium silicates, and alkaline (containing calcium, potassium, and sodium) rocks.

In crystallizing magmas, ferrotitanium oxides form in two ways:

1. By direct precipitation of ilmenite or ilmenite-hematite solid solution or ulvospinel-magnetite $\left(\mathrm{TiFe}_{2} \mathrm{O}_{4}\right)$ solid solution; the earliest formed oxides have the highest titanium-to-iron ratios.

2. By breakdown of iron-bearing pyroxenes $[(\mathrm{Mg}, \mathrm{Fe}, \mathrm{Ti})$ $\left.\mathrm{Si}_{2} \mathrm{O}_{6}\right]$ at low oxygen pressures to form ilmenite and iron-free pyroxene.

The high specific gravities of these minerals indicate that they can be separated by gravity methods from more common light metals that surround them. The indices of refraction of the three varieties of titanium dioxide minerals are a measure of the opacity of these crystalline forms. This is of importance in their primary use as pigments because the "covering power" of the pigment is related to the opacity of its constituents.

\section{WORLD PRODUCTION}

More than one-half of the world's titanium mineral production is from ilmenite, leucoxene (altered ilmenite), and rutile from beach-complex placer deposits in Australia, India, South Africa, Sri Lanka, and the United States. A fluvial placer deposit in Sierra Leone also has produced a substantial quantity of rutile (Cristie and Brathwaite, 2007). Most of the remaining supply is recovered from hardrock ilmenite deposits in Canada, China, and Norway. Figure 2 shows world production for titanium minerals by type and country of origin in 2004.

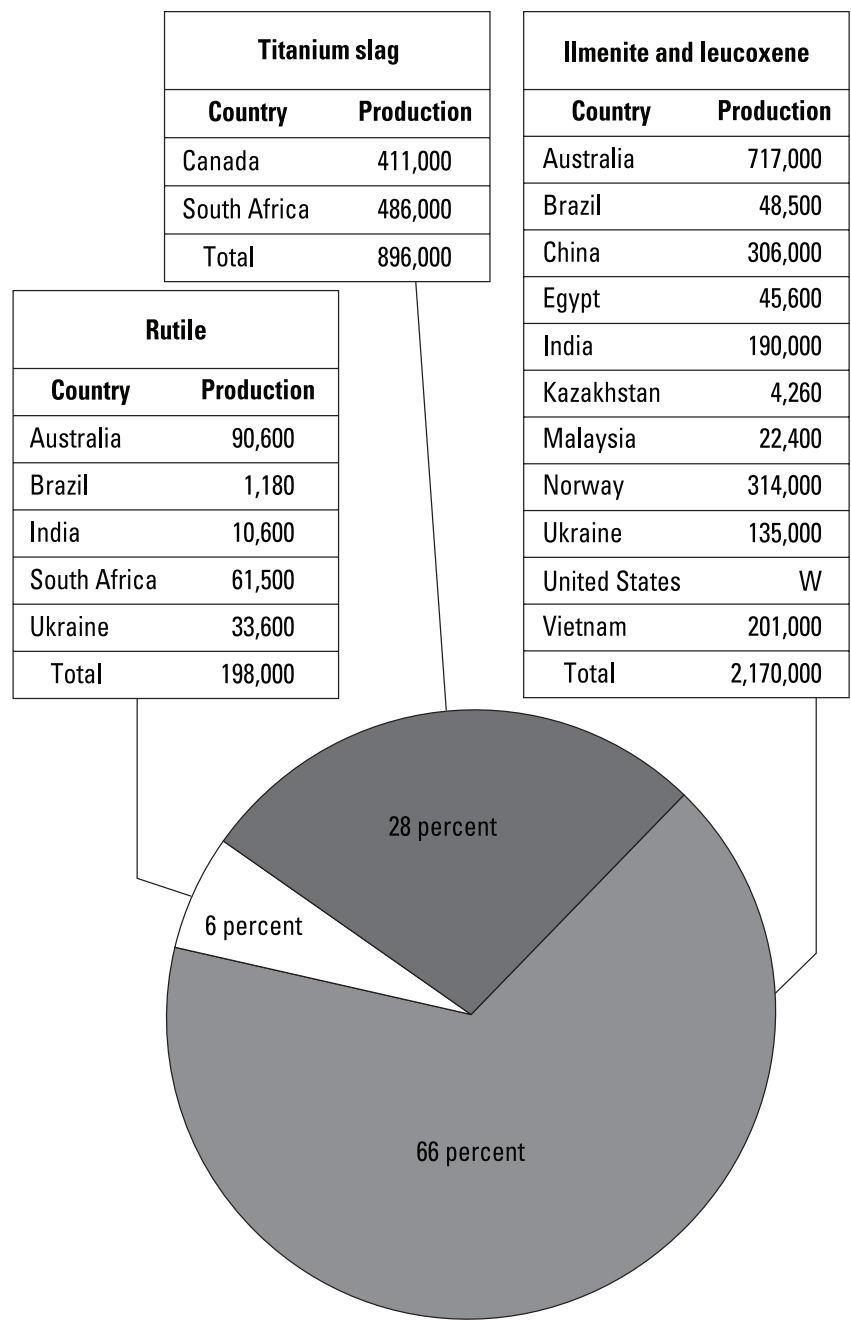

Figure 2. Diagram showing world production of titanium by mineral type and location in 2004 . Values are in metric tons of contained titanium are rounded to three significant figures. The addition of the parts may not equal the totals owing to independent rounding. $\mathrm{W}$, withheld to avoid disclosing company proprietary information. (Source: Gambogi, 2006.)

In 2004, 8.17 million metric tons (Mt) of materials (ilmenite, leucoxene, rutile, and titaniferrous slag) containing 3.26 Mt of titanium (66 percent from ilmenite and leucoxene, 28 percent from titaniferrous slag, and 6 percent from rutile) was produced worldwide.

\section{PRODUCTION PROCESSES}

This section of the report describes the details of the many titanium production processes, which taken together (fig. 3) transform titanium-containing ores into value-added products. 


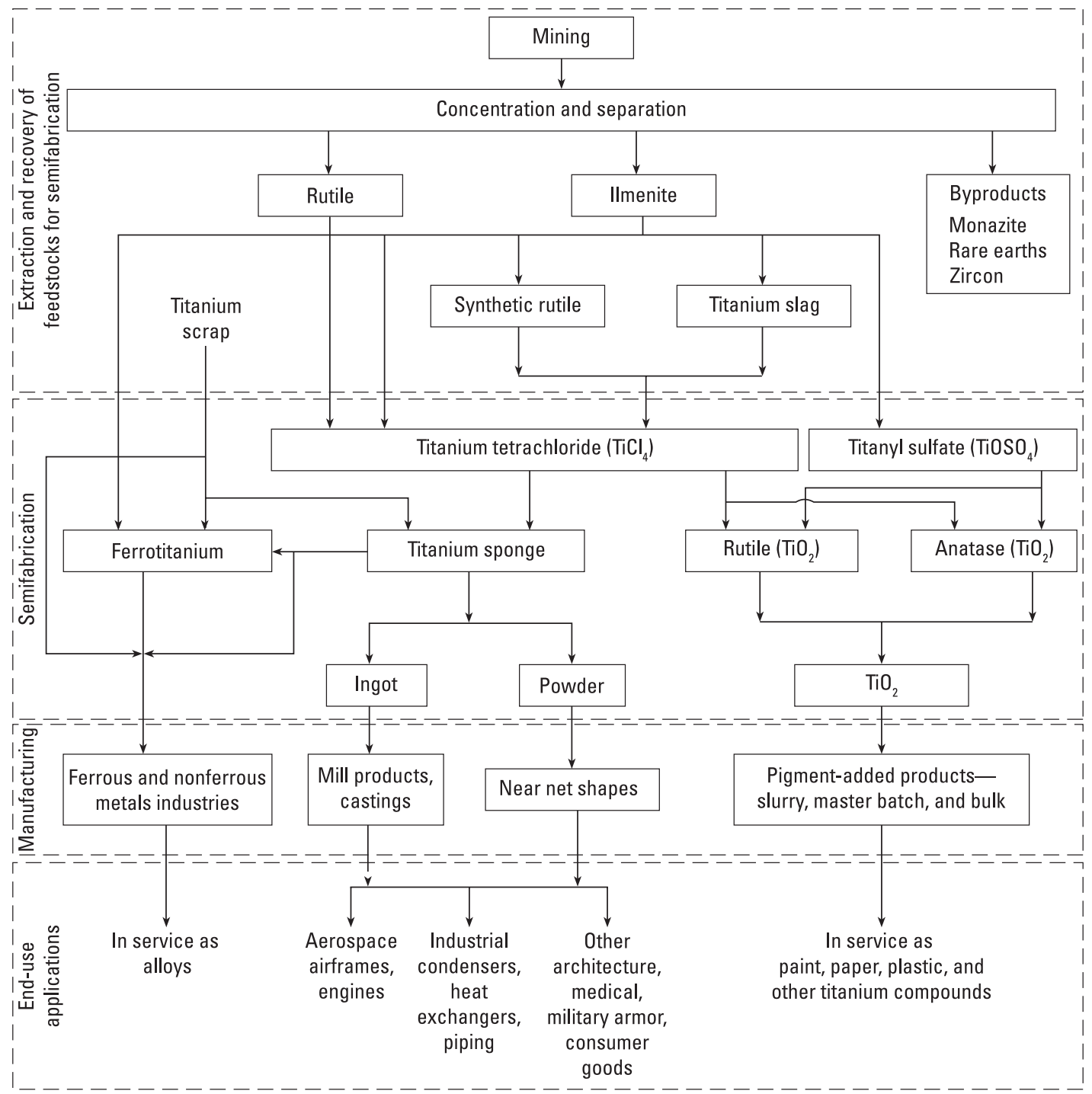

Figure 3. Diagram showing the production flows of titanium from extraction through placement into end-use service. (Sources: Gambogi, 2006; Australia Bureau of Agriculture and Resource Economics, 2008.)

\section{MINING, CONCENTRATING, AND ILMENITE UPGRADING PROCESSES}

This section covers the processing of titanium-containing oxide minerals (which are generally associated with other heavy minerals) into titanium and byproduct mineral concentrates. The principal product of mining operations is a mixture of heavy minerals. The mining method selected depends on the location of the deposit. Dredging is suitable for beach deposits; dry-land deposits are scraped and screened. The next step is wet concentration, where the materials are put through a system of spirals and cones to separate the high specific gravity materials (which contain the titanium and other heavy minerals) from the low specific gravity minerals (which are rejected and used for reclamation). The separated heavy minerals are then dried before undergoing magnetic separation. The ilmenite and leucoxene minerals are slightly magnetic and can be separated from the remaining heavy minerals by means of magnetic separation. Additional magnetic and electrostatic separation produces the coproducts, which include monazite, rutile, zircon, and others depending on the nature of the original mineral deposit (Australia Bureau of Agriculture and Resource Economics, 2008). 


\section{SEMIFABRICATION PROCESSES (METAL)}

There are three principal titanium-containing semifabricated metal products that are supplied to downstream manufacturers. These include titanium sponge, titanium ingot (which supplies unwrought, wrought, and cast products), and ferrotitanium (an alloy made specifically for steelmaking). Because this report focuses on titanium metals flows, there will be no discussion of the semifabrication and manufacturing process for titanium compounds, including oxides for pigment applications.

\section{TITANIUM SPONGE (FOR ALLOY, METAL, AND POWDER PRODUCTS)}

Titanium sponge production begins with a feed of titanium tetrachloride formed from the Kroll process, a process that chlorinates titanium oxide concentrate. The Kroll process has not changed very much since its commercialization in 1948 and is still used to convert titanium tetrachloride to titanium metal sponge. Figure 4 shows the steps of the Kroll process.

In the first step of the Kroll process, a vacuum is created in a clean and dry stainless steel retort. Next, inert argon gas is pumped into the retort under reduced pressure. Then, magnesium metal [ 15 to 30 percent more than the chemical requirement necessary to reduce the titanium in titanium tetrachloride $\left(\mathrm{TiCl}_{4}\right)$ gas to titanium metal] is placed into the retort. $\mathrm{TiCl}_{4}$ gas is slowly fed into the retort where it reacts with the magnesium metal to produce titanium sponge and magnesium chloride $\left(\mathrm{MgCl}_{2}\right)$. The $\mathrm{MgCl}_{2}$ is periodically removed from the retort as reduction proceeds over several days. In the final step, the retort contains the titanium sponge, some unreacted magnesium, and some $\mathrm{MgCl}_{2}$, at which point, either the titanium sponge is removed and the retort undergoes an inert gas sweep followed by acid leaching or the retort undergoes vacuum distillation to remove the unwanted magnesium products and the titanium sponge is mechanically removed from the retort. The titanium sponge is then melted, sometimes with scrap and (or) alloying elements, to produce an ingot with a specified chemistry (Gerdemann, 2001).

Titanium in various forms can be treated by patented processes to produce titanium powders of different types. Powder metallurgy techniques use pressure and temperature to create near-net shapes, thus conserving metal loss from machining of wrought products made from ingot material.

\section{TITANIUM INGOT, UNWROUGHT, WROUGHT, AND CASTING PRODUCTS}

Titanium ingot production involves blending and melting such input materials as sponge, scrap, and master alloys, usually under inert gas or vacuum, and may require several remelts to obtain the desired purity of a titanium metal product or the desired chemical makeup of a titanium alloy. The resulting ingots are worked by mechanical processes (analogous to steel mill practices) into billet and slab, which in turn undergo additional physical alteration to obtain saleable wrought forms, such as bar, foil, and plate. These forms are fabricated into specific parts and shapes, which manufacturers assemble

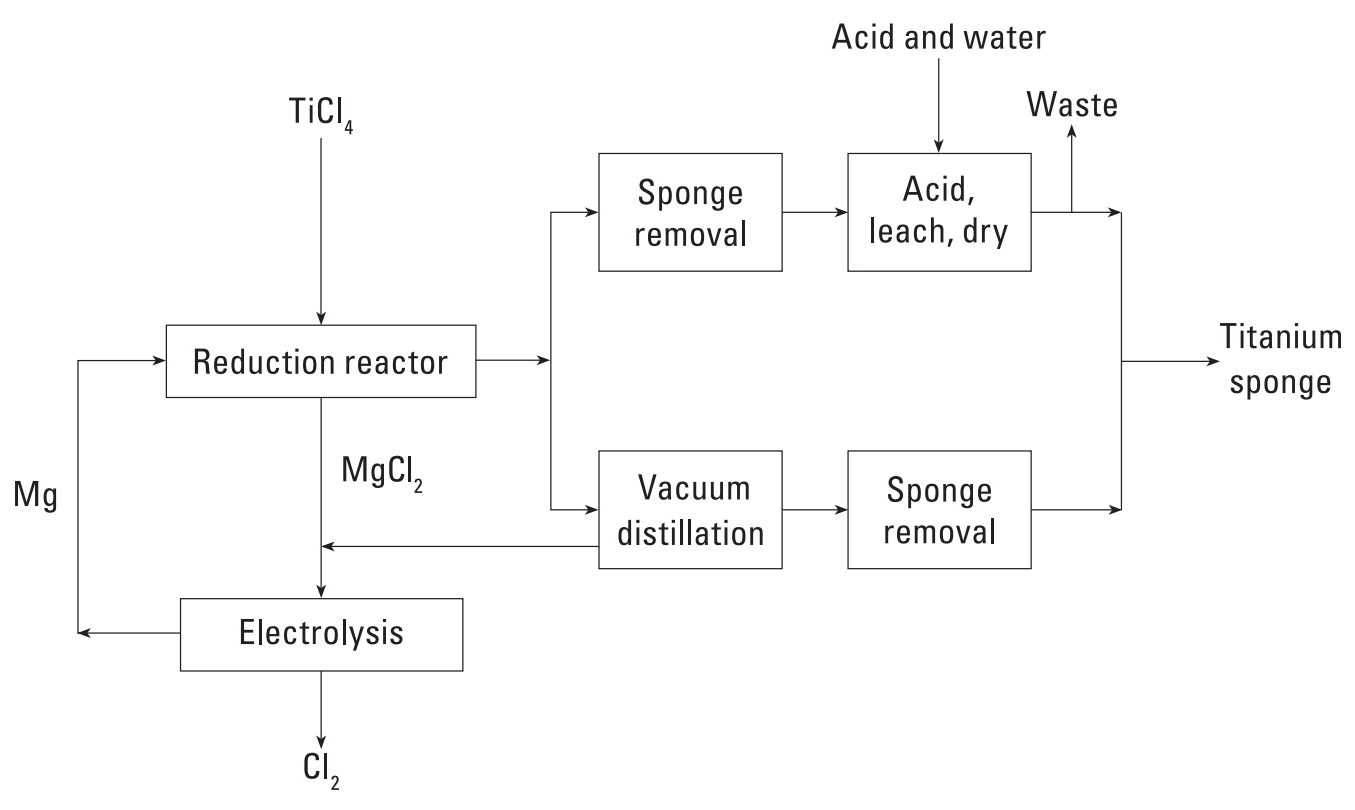

Figure 4. Diagram showing the steps of the Kroll process for the production of titanium sponge. (Sources: Australia Department of Industry, Science and Resources, 2001; Gerdemann, 2001.) 
with nontitanium materials to make products such as airframes and engine turbines. This kind of processing generates a large volume of home scrap and new (prompt) scrap, which usually returns to the ingot production step.

\section{FERROTITANIUM PRODUCTS}

Ferrotitanium can be produced either from ilmenite or from primary and secondary metal. In recent years, the availability of titanium scrap on the market has increased, and production of ferrotitanium from secondary raw materials has subsequently gained ground (German Federal Environmental Agency, 2001, p. 520).

Ferrotitanium is usually produced by melting ferrous scrap and titanium scrap and metal in an induction-melting or electroslag furnace (fig. 5). Ferrous units are purchased to a specification in the form of mild steel solids. Titanium scrap includes various forms such as scrap metal castings, wrought products, and turnings and (or) chips (otherwise known as swarf) from machining processes. Prior to melting the

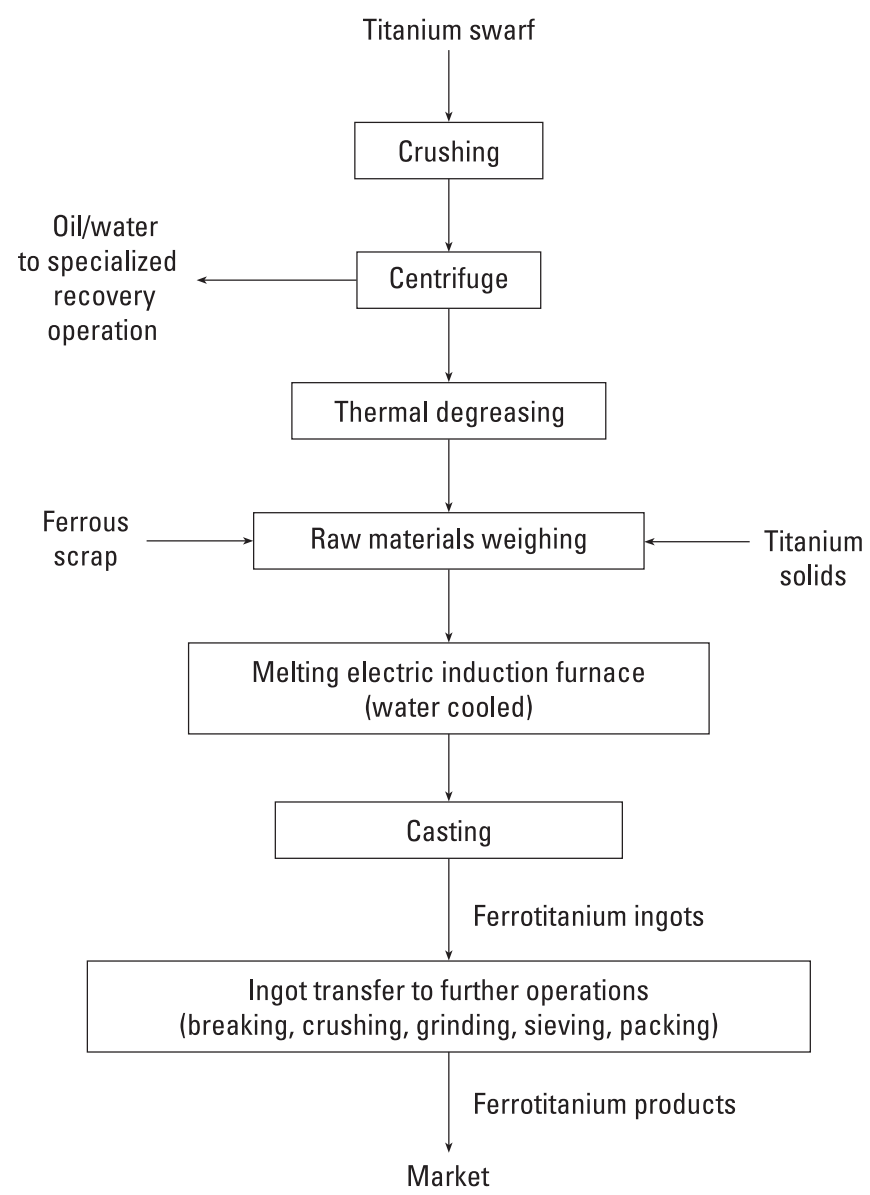

Figure 5. Diagram showing the process flow for the production of ferrotitanium. (Source: German Federal Environmental Agency, 2001.) material in a furnace, large lumps of scrap are reduced in size, and swarf is pulverized and then degreased and dewatered (German Federal Environmental Agency, 2001, p. 521).

Furnace charges are calculated based on the analysis of the raw materials. When melting is complete, the molten metal is tapped into an ingot mold. After cooling, the ingot is transferred to other operations such as breaking, crushing and grinding to achieve the required product size

\section{MANUFACTURING PROCESSES}

Semifabricated titanium-containing products (ferrotitanium, metal ingots, and powders) must undergo further manufacturing to produce products that provide serviceability in a desired end-use application. Ferrotitanium and titanium metal and scrap are used in steelmaking. Titanium-containing ingots and powders are processed into castings, forgings, and mill products.

\section{STEEL (TITANIUM-CONTAINING ALLOYS)}

In 2004, about 7,000 t of titanium (about 16 percent of estimated U.S. titanium consumption) was consumed by U.S. steelmaking and other industries. Figure 6 shows the distribution (by steel product) of gross titanium alloys consumed by the U.S. steel industry from 1980 through 2004.

Carbon steel. - In 2004, 4,200 t (48 percent) of titaniumcontaining alloys used within the U.S. steelmaking activity was consumed in the production of carbon steel. From 1985 through 2004, titanium use in carbon steel production has grown at an average annual rate of 24 percent. Titanium modifies the properties of carbon steels by metallurgical control of grain size (smaller crystals), precipitation strengthening, and sulfide shape control. Microalloying with small amounts of titanium makes the product stronger (permitting weight reduction), more easily formed (cutting manufacturing costs), and less susceptible to corrosion (extending product life) (Key-to-Metals, 2008). Because titanium partitions to slag under oxidizing conditions, it is usually imparted to steel (previously deoxidized by manganese and silicon) as a ladle addition.

Stainless and heat-resisting steel.-In contrast to carbon steel, in which titanium additions were found to impart significantly improved properties in steel applications since 1987, titanium use in stainless and heat-resisting steel has always been important. In these types of steel, titanium is added because it competes successfully with chromium, a principal component in stainless steel, for the residual carbon retained in the alloy. Chromium carbide migrates to grain boundaries at elevated temperatures, degrading the strength and corrosionresistance of the steel. Titanium additions prevent the formation of chromium carbide, enabling the steel to retain the desired properties at elevated service temperatures.

In $2004,3,100 \mathrm{t}$ (36 percent) of titanium alloy used within the U.S. steelmaking activity was consumed in the 


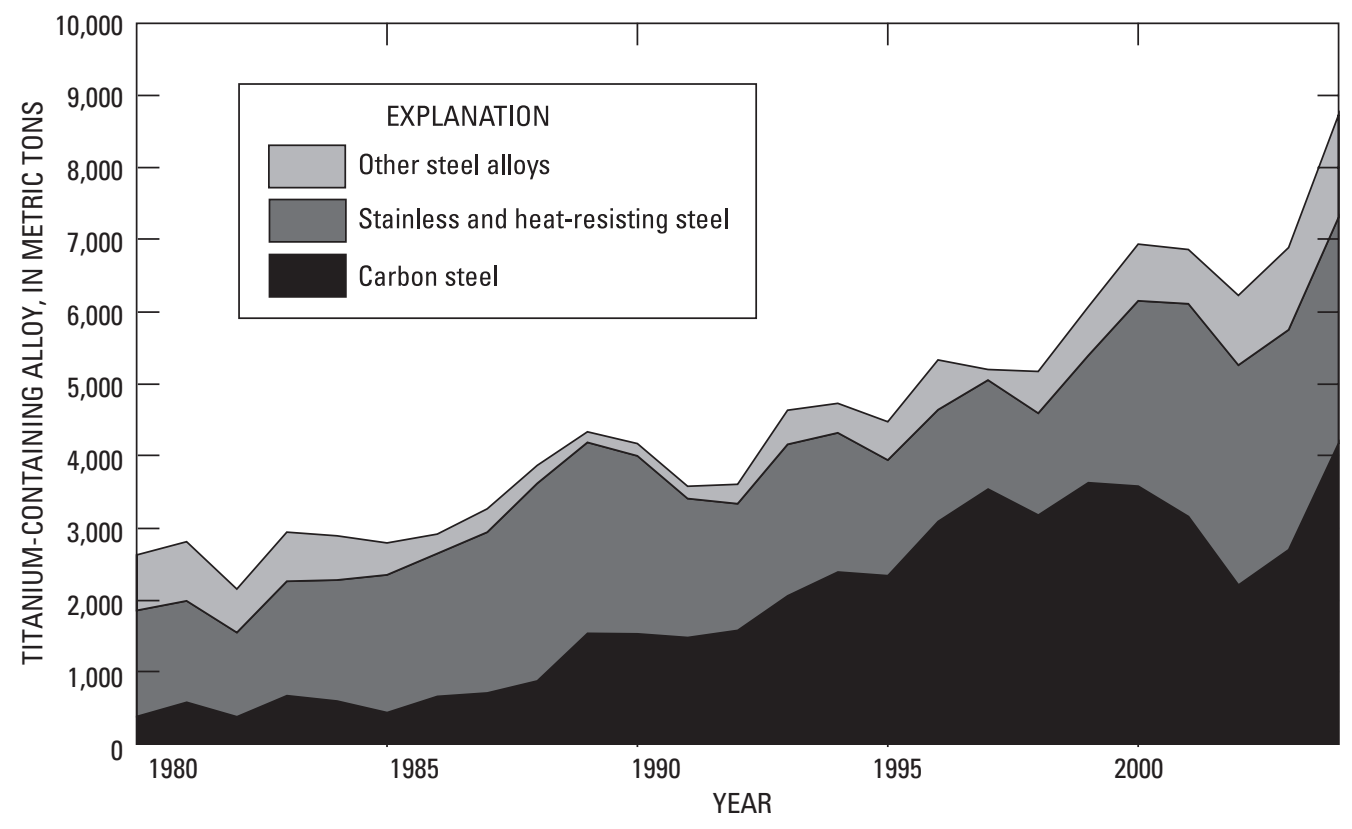

Figure 6. Diagram showing the distribution of gross titanium alloys consumed by the U.S. steel industry, by steel product, from 1980 through 2004. (Source: Gambogi, 2006.)

production of stainless and heat-resisting steel. From 1985 through 2004, titanium alloy usage in stainless and heatresisting steel production has followed the growth in the usage of the steel at an average annual rate of 2 percent.

Other steel.-The exact nature of the applications in this category of titanium alloy use is unknown. However, the average annual rate growth rate of 45 percent for the period from 1985 through 2004 is greater than that for carbon steel, which seems to indicate that steels in this category are realizing the same improvements in their strength-to-weight ratio that titanium-modified carbon steels attain. In 2004, 1,400 t (16 percent) of titanium alloy used within the U.S. steelmaking activity was consumed in the production of other steel alloys.

\section{ASSEMBLIES}

Titanium product assemblies are products that partly comprise semifabricated titanium-containing materials, which may include titanium metal or titanium alloys. For example, titanium alloys are used by manufacturers to make airframes, chemical processing tanks, and turbines. Titanium metal product semifabrication and manufacturing of assemblies generate scrap, both during processing (new and home scrap) and after economic life (old scrap).

\section{END USE OF TITANIUM-CONTAINING METALS}

In 2004, U.S. primary titanium metals producers supplied the market with about 45,000 t of titanium metal. Figure 7 shows U.S. apparent consumption of titanium sponge and scrap, for the period 1975 through 2004.

In 2004 , about $38,000 \mathrm{t}$ of titanium metal contained in ingot was consumed by U.S. semifabricators (castings and wrought and unwrought) of titanium products. With regard to the sponge fraction of ingot production, the aerospace sector of the economy consumed 60 percent of the output; the remainding 30 percent was consumed by other applications (U.S. Geological Survey, 2006). The end-use allocation for scrap is not reported.

Titanium sponge use in U.S. aerospace applications from 1975 through 2004 has been cyclical, averaging about $14,300 \mathrm{t}$ of titanium annually. These data do not include the titanium contained in net exports for assemblies (parts) for aircraft or for net exports of assembled aircraft. In 2007, U.S. exports of aircraft and aircraft parts exceeded imports of the same by a factor of three (in terms of value) (Kogon, 2007). This suggests, but certainly does not prove, that the United States may be a net exporter of titanium contained in aircraft assemblies. New aircraft designs are showing large-scale increases for titanium use (RTI International Metals, Inc. 2007, p. 7). The annual average growth trend for sponge use by "Other" was 4.7 percent per year for the same period. The annual growth rate trend for titanium scrap use in U.S. industrial applications (1975-2004) was about 4 percent. 


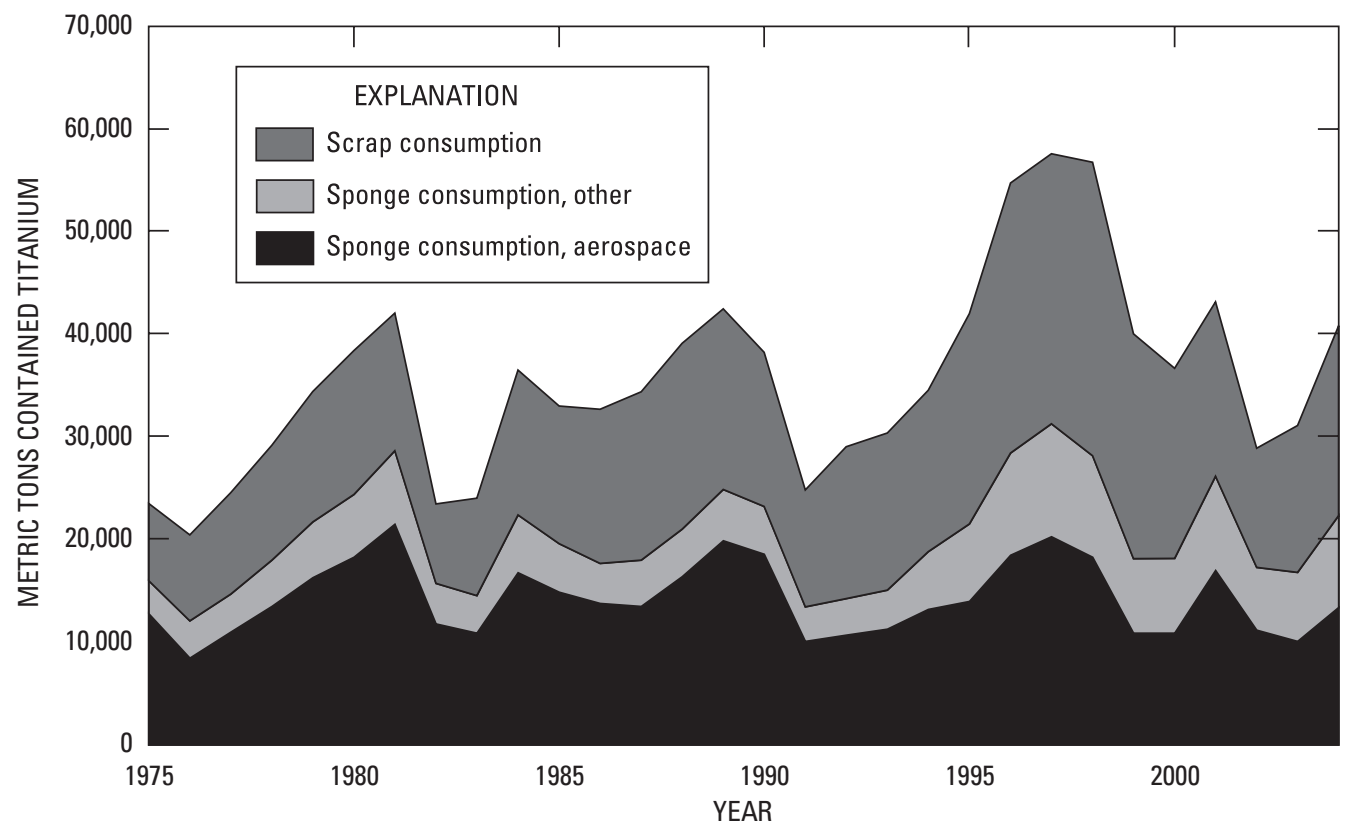

Figure 7. Chart showing U.S. apparent consumption of titanium sponge and scrap, with refinement by economic sector (for sponge), from 1975 through 2004. (Source: U.S. Geological Survey, 2006.)

\section{PRICES}

From 1994 through 2004, titanium sponge nominal prices averaged $\$ 7.91$ per kilogram with variance of \pm 15 percent (fig. 8). The constant dollar price of titanium sponge declined by about 1 percent per year on average, while reported U.S. consumption of titanium sponge increased by about 2.3 percent per year.

The average nominal dollar price of scrap from 1994 through 2004 was $\$ 2.54$ per kilogram with variance of \pm 84 percent, almost fivefold that for sponge (fig. 9). The constant dollar price of scrap increased by about 28 percent per year. However, without the spike in constant dollar scrap prices for 2003-06, which was owing to the convergence of several economic factors (the end of sales from the national stockpile and strong steel and aerospace demand), the average constant dollar scrap price growth might have been much less. This was also the period when the United States was a net exporter of titanium waste and scrap. The principal destinations for U.S. exports of titanium scrap were Japan and the United Kingdom.

\section{SOURCES AND DISPOSITION OF TITANIUM SCRAP}

There are two necessary conditions for recycling to take place. First, there must be a supply of material. Many materials dissipate with use and cannot be recycled-for example paint (which contains titanium pigment). Many metals, titanium metal included, retain their mass while in service. They may lose economic utility but little or none of their mass. These are candidates for recycling, and there is a ready supply of these materials. The second necessary condition is that the cost of identifying, collecting, processing, and transporting scrap materials must be low enough to provide a profit margin for an entity that would perform those tasks. Metals are relatively scarce and thus generally have prices high enough to cover the recycler's costs and provide the recycler's required margin. During periods of low prices for titanium metal scrap, margins for scrap processors may decrease, and the cost of collection for certain scrap types may become prohibitive, thereby reducing the recovery of titanium from scrap. When titanium metal scrap prices are relatively high, titanium recovery from scrap would be expected to increase. This section examines the sources and distribution of recyclable titanium scrap, both new and old.

In 2004, about 3,000 $\mathrm{t}$ of titanium (contained in old scrap) was generated from the U.S. titanium product reservoir (Joseph Gambogi, U.S. Geological Survey, written commun., May 13, 2009). In addition, roughly 25,000 $\mathrm{t}$ of titanium was recovered from new scrap. While the use of old scrap is mostly undocumented, most of the recovered new and home scrap is recovered and recycled, either domestically or by foreign entities through scrap trade.

\section{OLD SCRAP}

Old titanium scrap includes obsolete parts, such as parts from aircraft and heat exchangers. In general, obsolete 


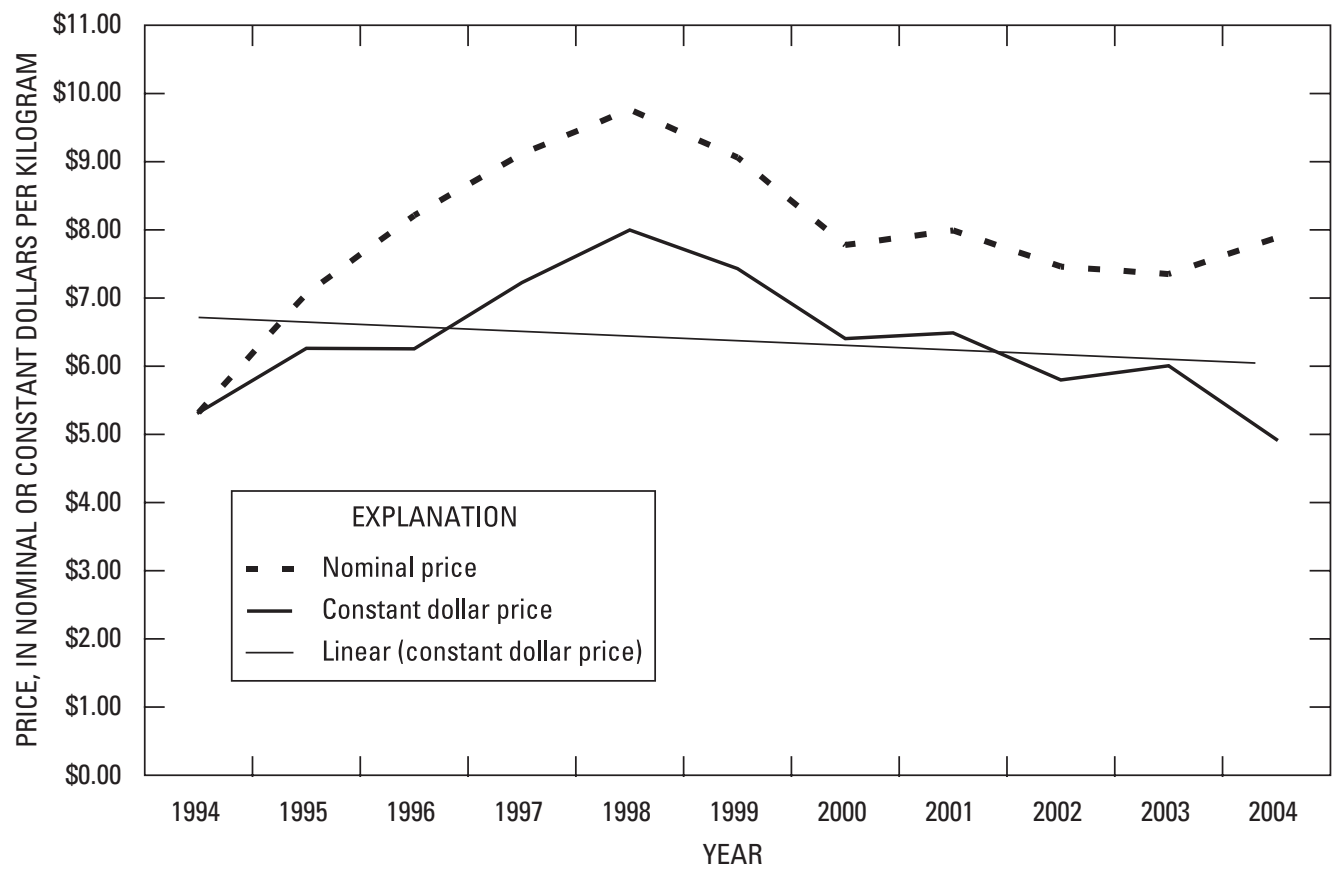

Figure 8. Chart showing titanium sponge prices from 1994 through 2004. Values are in dollars (nominal and 1994 dollars) per kilogram. The nominal price is taken as the average of Japanese and Russian landed duty-paid unit values based on imports for consumption into the United States. Constant dollars are based on discounting nominal dollar prices using the Producer Price Index (1994 basis), which applies to mill prices. (Sources: U.S. Department of Labor, Bureau of Labor Statistics, 2009; Joseph Gambogi, U.S. Geological Survey, written commun., March 4, 2009.)

titanium scrap is not effectively utilized because only about 2 percent of ingot production uses old titanium scrap. However, some obsolete parts are used to manufacture wrought titanium to the SAE International aerospace material specification (http://aerospace.sae.org/) after rigorous selection (Ishii and others, 2000).

Old scrap recycling efficiency is defined as the amount of old scrap recovered and reused relative to the amount available to be recovered and reused-that is, consumption of old scrap (COS) plus exports of old scrap (OSE) divided by old scrap generated (OSG) plus imports of old scrap (OSI) plus a decrease in old scrap stocks (OSS) or minus an increase in old scrap stocks, measured in weight and expressed as a percentage. In this analysis, consumption of old scrap is equal to the measured titanium recovered from old scrap. In 2004, the domestic old scrap recycling efficiency for titanium metal could not be calculated because of critical missing data.

The recycling rate is that fraction of annual apparent metal supply that is derived from scrap - that is, consumption of old scrap (COS) plus consumption of new scrap (CNS) divided by apparent copper supply (AS), measured in weight and expressed as a percentage. In 2004, the recycling rate for titanium metal could not be calculated because of critical missing data.

The new to old scrap recovery ratio in the United States is the ratio of the percentage of titanium metal in new scrap recovered to the percentage of titanium metal in old scrap recovered in U.S. titanium metal production. In 2004, the new-scrap to old-scrap ratio for the United States could not be calculated because of missing data, but was greater than 7 , based on the data reported in figure 1.

\section{OLD SCRAP GENERATED}

In 2004, the U.S. Geological Survey estimated that 3,000 $\mathrm{t}$ of titanium metal contained in old scrap was generated as end-of-life material from the U.S. reservoir of titanium products in service (Joseph Gambogi, U.S. Geological Survey, written commun., May 13, 2009).

\section{OLD SCRAP UNRECOVERED}

Old scrap unrecovered could be located in several places. It could be abandoned in place (hibernating) pending suitable 


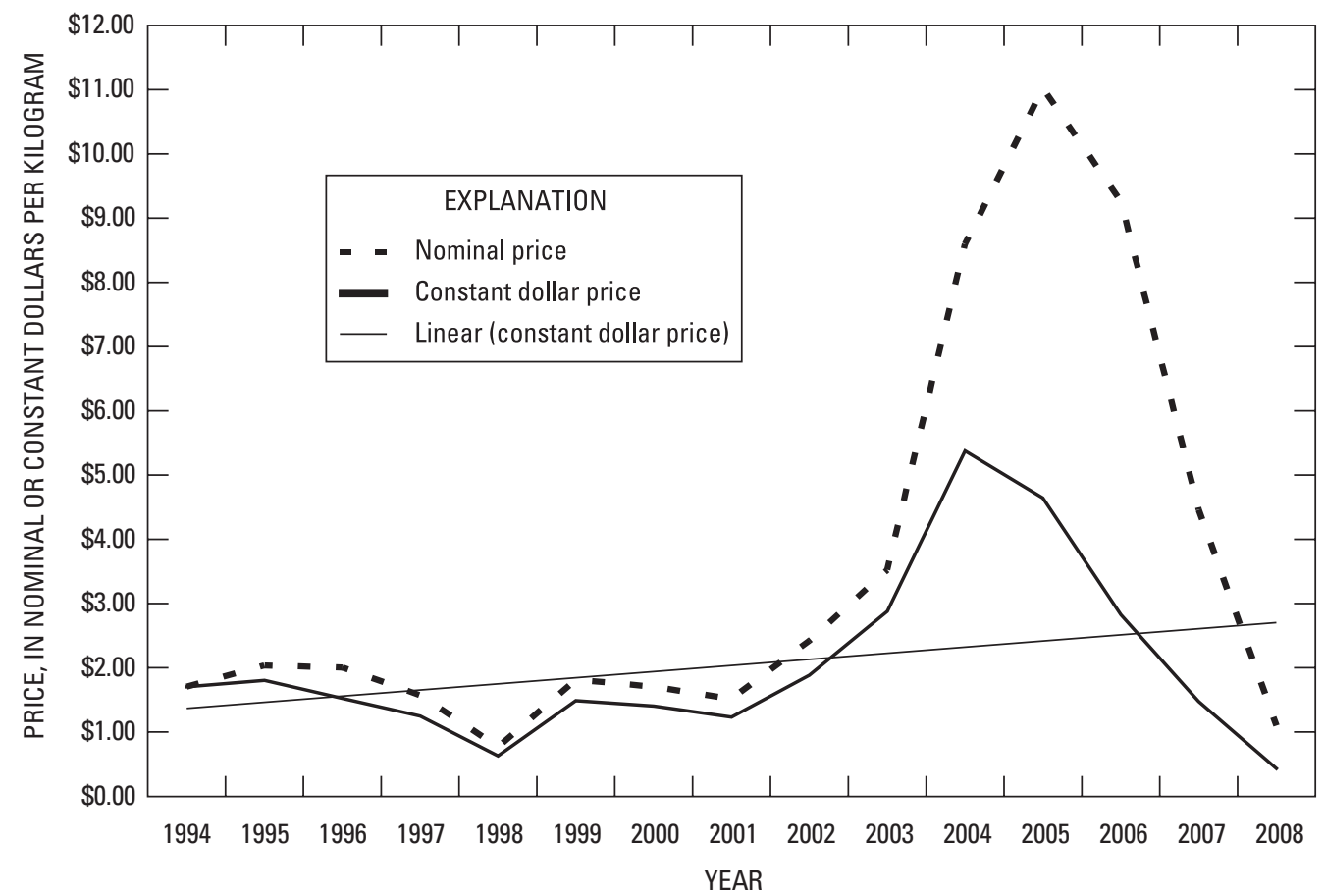

Figure 9. Chart showing titanium scrap prices from 1994 through 2004. Values are in dollars (nominal and 1994 dollars) per kilogram. The nominal price is taken as taken as that reported by Platts Metals Week for unprocessed turnings of Ti-6Al-4V alloy. Constant dollars are based on discounting nominal dollar prices using the Producer Price Index (1994 basis). (Sources: U.S. Department of Labor, Bureau of Labor Statistics, 2009; Joseph Gambogi, U.S. Geological Survey, written commun., March 4, 2009.)

economic incentives (scrap prices) to warrant collection and processing; it might have been collected and placed in landfills, which would potentially conserve it for a time of better prices; or it might have been dissipated during use. The 3,000 t reported in figure 1 as old scrap unrecovered is the amount that would balance inputs and outputs reported in the figure and is therefore an artifact of the accounting process of the materials flow.

\section{NEW SCRAP}

Titanium scrap supply in 2004 contained 28,000 t of titanium (fig. 1). Of this amount, 25,000 t of titanium was contained in new scrap, of which 56 percent was generated in semifabrication operations, and 44 percent was generated from downstream manufacturing operations. In 2004, $20,000 \mathrm{t}$ of titanium contained in semifabricated products was supplied to downstream manufacturing operations, 60 percent going to aerospace applications, and the remaining 40 percent allocated to other applications.

Within the aerospace sector, there is a high level of scrap generation during the production of final-use parts, such that the sector has evolved the term "buy-to-fly" ratio to express the relationship of the amount of material required to generate a final part (Michaels, 2008). It is essentially the reciprocal of useful material recovery for aerospace part fabrication. For example, a "buy-to-fly" ratio of 7:1 translates to a recovery factor of 14 percent and a scrap generation rate of 86 percent. It was estimated that the "buy-to-fly" ratio for the aerospace sector in 2004 was about 5:1 and that useful product amounted to about 20 percent of $12,000 \mathrm{t}$ of titanium delivered to the sector or $2,400 \mathrm{t}$ of titanium, and that new scrap generated from the sector contained about $10,000 \mathrm{t}$ of titanium.

\section{ALL SCRAP}

Throughout the Circular 1196 series of recycling reports, it has been possible to generate some standard recycling statistics (see appendix) based on information about the split between the use of old scrap and new scrap. The exact split for titanium, however, is unknown. Therefore, some new statistics, which are somewhat analogous to the other reports, are offered here with respect to the new scrap plus old scrap collective, that is "all scrap" (table 1). 

follows:

The all-scrap recycling efficiency is calculated as U.S. consumption of all scrap + U.S. exports of all scrap U.S. generation of all scrap + U.S. imports of all scrap increase of all U.S. scrap stocks

which equals:

$$
\frac{200,000 t+9,000 t}{28,000 t+8,000 t-3,000 t}
$$

In 2004, the all scrap recycling efficiency was 91 percent.

The all-scrap recycling rate is that fraction of annual apparent metal supply that is derived from all-scrap consumption divided by apparent titanium supply, measured in weight and expressed as a percentage. In 2004, the recycling rate for titanium all titanium-containing scrap was 52 percent of apparent titanium metal supply.

\section{PROCESSING OF TITANIUM SCRAP}

The collection and handling of new titanium metal scrap are fairly straightforward. New scrap is generated during semifabrication and manufacturing operations and consists of such items as clippings, stampings, and turnings. These are usually segregated by material specification and returned to furnace operations where the scrap is matched and melted into a product with the desired chemistry.

Old (obsolete) scrap originates when products that are within the reservoir of products in service are no longer economical to use. In the past, old titanium scrap has had a tendency to hibernate because the stringency of titanium metal and alloy specifications mitigated its use. In recent years, more old scrap is being recovered, but not to the point of reliable reporting.

\section{TITANIUM SCRAP TRADE}

Titanium contained in various forms and mixtures flows through the international scrap trade (fig. 10). In 2004, 10,000 $\mathrm{t}$ of titanium scrap was exported from the United States, and $9,000 \mathrm{t}$ of titanium scrap was imported. Japan provided the greatest percentage of U.S. titanium scrap imports (27 percent).

\section{OUTLOOK}

Owing to the superior high-temperature strength and corrosion resistance of titanium metal and titanium alloys, titanium likely will continue to be in demand on a worldwide basis. The titanium market was highly volatile for the period from 1972 through 2004, showing a 26 percent variance about the average for sponge

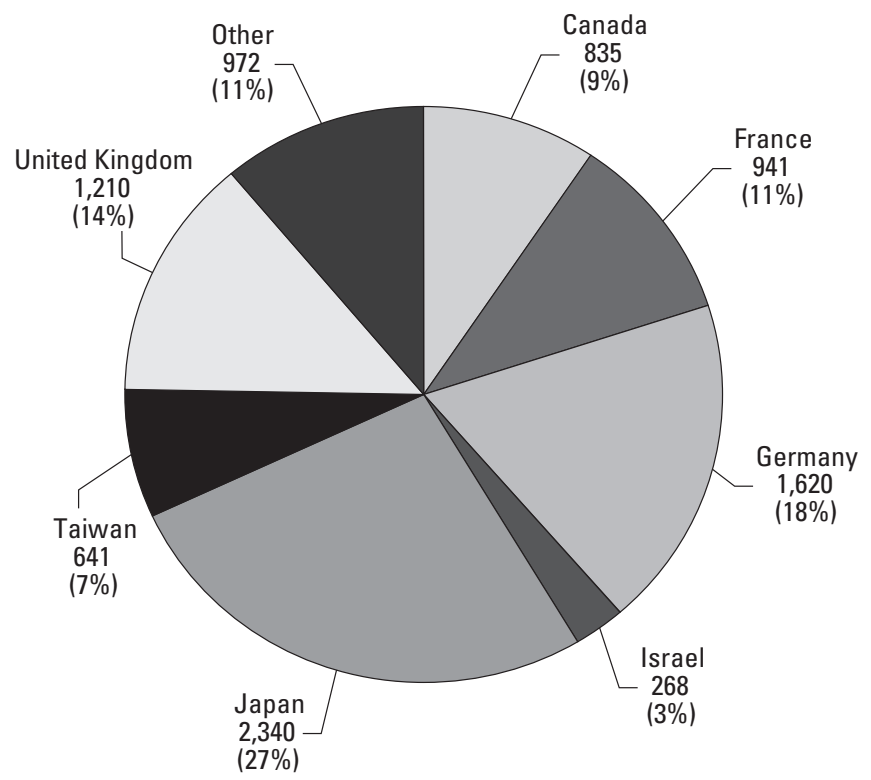

Figure 10. Chart showing sources of U.S. titanium scrap imports, by country, in 2004. Values are in gross metric tons and percentage of total imports. (Source: Gambogi, 2006.)

consumption, 28 percent about the average for ingot production, and 37 percent about the average for scrap consumption. Supplies seem adequate, although titanium sponge prices in 2004 were more than twice what they were in 1994 (in constant dollars). From 1972 through 2004, the average annual growth for U.S. titanium ingot production was about 2 percent. For the 33 -year period, the average annual consumption growth rates for scrap and sponge, the major components of ingots, were 5.0 and 0.8 , respectively, inferring that the U.S. titanium metals market is viable and growing and that more and more scrap is being utilized to make these metal products (fig. 11).

Titanium recycling can be expected to continue for these principal reasons:

1. The titanium metal market is growing (for example, aircraft being constructed after 2008 call for more titanium those manufactured before 2008, and new uses for titanium in industrial and consumer goods are being developed) and likely will continue to generate scrap (new and old).

2. About 200 aircraft per year were expected to become obsolete after 2005 (Burchell, 2006).

3. The scrap-to-sponge ratio has been increasing as improvements in titanium scrap recovery systems have made scrap a more acceptable source of raw materials for ingot production.

Pressure from titanium industry stockholders to improve corporate performance likely will continue, which often 


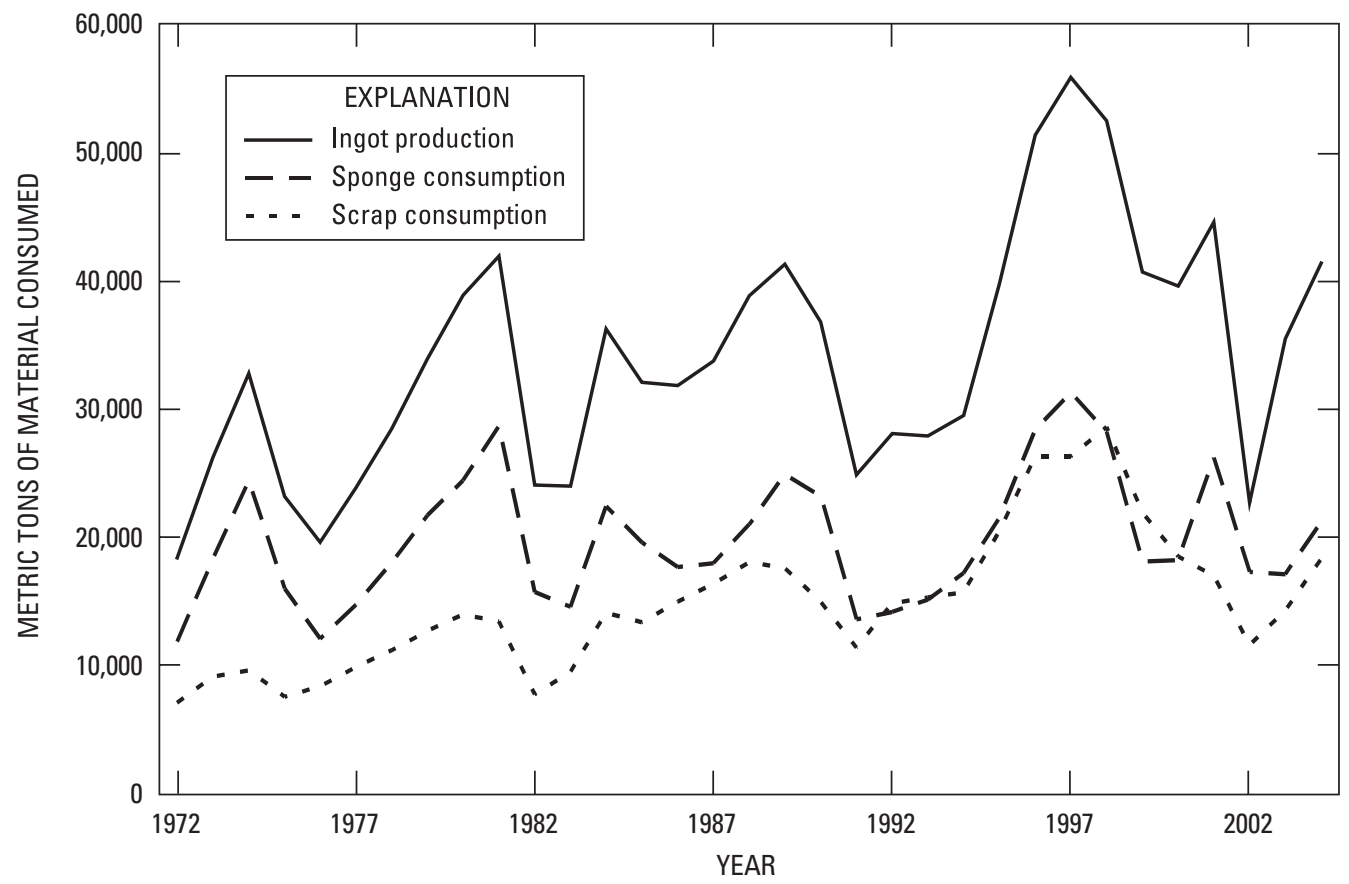

Figure 11. Chart showing titanium scrap and sponge consumption and ingot production from 1972 through 2004. (Source: Gambogi, 2006.)

means cost reduction through incremental technological improvements to enhance product recoveries. Stakeholders can be expected to push for improved resource efficiencies through recycling mandates where the economics may not justify recycling. U.S. and worldwide titanium processing capacity has been expanding, which should increase titanium recycling and exports of U.S. titanium scrap (Gorse, 2006).

\section{REFERENCES CITED}

Australia Bureau of Agriculture and Resource Economics, 2008, Research and development in titaniumImplications for the titanium metal industry of Australia: Australia Bureau of Agriculture and Resource Economics, accessed October 20, 2008, at URL http://www.abareconomics.com/interactive/ 08_ResearchReports/Titanium/htm/chapter_2.htm.

Australia Department of Industry, Science and Resources, 2001, Titanium metal—A market analysis: Australia Department of Industry, Science and Resources Emerging Industries Occasional Paper 7, February 2001, 28 p.

AZoM TM.com Pty. Ltd., 2009, Titanium alloys-Alpha, beta, and alpha-beta alloys: AZoM TM.com Pty. Ltd. Web site, accessed February 27, 2009, at URL http://www.axom.com/Details.asp?ArticleID=915.

Burchell, Bill, 2006, Recycling aircraft-Overhaul and maintenance: Aviation Week, March
24, accessed December 30, 2008, at URL http://www.aviationweek.com/aw/generic/ story_generic.jsp?channel=om \&id=news / om206pam.xml.

Cristie, Tony, and Brathwaite, Bob, 2007, Mineral commodity report 16-Titanium: New Zealand Ministry of Economic Development, Crown Minerals Web site, accessed September 26, 2008, at URL http://www.crownminerals.govt.nz/cms/pdf-library/ minerals/minerals-overview-pdfs-1/report16_titanium.pdf.

Gambogi, Joseph, 2006, Titanium, in Metals and minerals: U.S. Geological Survey Minerals Yearbook 2005, v. I., p. 78.1-78.17. (Also available online at http://minerals.er.usgs.gov/minerals/pubs/commodity/ titanium/titanmyb05.pdf.)

Gerdemann, S.J., 2001, Titanium process technologies: Advanced Materials and Processes, July, 3 p., accessed October 1, 2008, at URL http://www.itponline.com/ index_files/ASMarticle.pdf.

German Federal Environmental Agency, 2001, Integrated pollution prevention control-Reference document on best available techniques in the non ferrous metals industries: European Commission, 755 p., accessed November 3, 2008, at URL http://www.bvt.umweltbundesamt.de/archive/ nonferrousmetalbrefe.pdf.

Gorse, Mathieu, 2006, French plant to cash in on aircraft recycling boom: Agence France-Presse 
Web site, accessed January 29, 2010, at URL http://www.spacewar.com/reports/French_Plant_To_ Cash_In_On_Aircraft_Recycling_Boom.html.

Ishii, Mitsuo, Kimura, Kinichi, and Kinoshita, Kazuhiro, 2000, Titanium products as environmentally friendly materials: Nippon Steel Technical Report 81, January, accessed December 30, 2008, at URL http://www.nsc.co.jp/en/tech/report/pdf/8120.pdf.

Key-to-Metals, 2008, Cast steel-Quenched and tempered low-alloy steel: Key to Metals AG knowledge article, accessed November 18, 2008, at URL http://steel.keytometals.com/Articles/Art87.htm.

Klemic, Harry, Sherman, P.M., and Cooper, Margaret, 1973, Titanium, in Brobst, D.A., and Pratt, W.P., eds., United States Mineral Resources: U.S. Geological Survey Professional Paper 820, p. 653-665, accessed January 29, 2010, at URL http://pubs.er.usgs.gov/djvu/PP/ pp_820.djvu.

Kogon, Maurice, 2007, U.S. aerospace export potentialTrends in U.S. exports and world demand: International Business Issue Forum, Torrance, Calif., February 22, 2007, Presentation, 19 p., accessed March 20, 2009, at URL http://www.californiaspaceauthority.org/images/ Powerpoint/USAeorspaceexports.ppt\#256, 1.

Michaels, Kevin, 2008, Outlook for the aerospace metals market: American Metals Market Annual Aerospace
Metals Conference, 2d, April 16, 2008, Pittsburgh, Pa., Presentation, 22 p., accessed May 4, 2009, at URL http://www.aerospace.com/downloads/speeches/ speech_65.pdf.

RTI International Metals, Inc., 2007, New programs take flight: RTI International Metals, Inc., 64 p., accessed January 14, 2009, at URL http://rtiintl.s3.amazonaws.com/RTI-Reports/ RTI_AR-2007.pdf.

Suisman, Michael, and Wasserman, Leonard, 1989, Recycling of titanium, in Properties and selectionNonferrous alloys and special purpose materials, v. 2 of Metals Handbook (10th ed.): Materials Park, Ohio, ASM International, p. 3376-3379, accessed January 29, 2010, at URL http://storage.worldispnetwork.com/ books/ASM_Metals_Handbook,Vol_02.pdf.

U.S. Department of Labor, Bureau of Labor Statistics, 2009, Producer price index-Commodities: U.S. Department of Labor, Bureau of Labor Statistics, accessed March 18, 2009, at URL http://data.bls.gov/.

U.S. Geological Survey, 2006, Titanium, in Kelly, T.D., and Matos, G.R., comps., Historical statistics for mineral and material commodities in the United States: U.S. Geological Survey Data Series 140, accessed May 12, 2006, at URL http://minerals.usgs.gov/ds/2005/140/. 


\section{APPENDIX-DEFINITIONS}

apparent consumption. Primary plus secondary production (old scrap) plus imports minus exports plus adjustments for U.S. Government and industry stock changes.

apparent supply. Apparent consumption plus consumption of new scrap.

hibernating scrap. Scrap that has reached the end of its useful economic life but has not been collected (remains in place) pending conditions that warrant the effort to collect it.

home scrap. Scrap generated as process or runaround scrap and consumed in the same plant where it was generated. It does not enter into trade and is not considered in this study.

master alloys. Alloys containing a primary element at levels more than 10 percent by weight. They serve as an intermediate material source in the manufacture of other alloys, or to deoxidize liquid metal baths.

mine waste. Rock materials having that are not ore grade at an ore deposit.

new scrap (prompt scrap). Scrap produced during the manufacture of metals and articles for both intermediate and ultimate consumption, including all defective finished or semifinished articles that must be reworked, and is obtained from a facility separate from the primary producer. Examples of new scrap are borings, castings, clippings, and turnings. Included as new scrap is prompt industrial scrap - scrap obtained from a facility separate from the primary processor. Excluded from new scrap is home scrap that is generated as process scrap and used in the same plant.

new-to-old-scrap ratio. New scrap consumption compared with old scrap consumption in the United States, measured in weight and expressed as new scrap divided by old scrap.

nominal price. The price at the time of sale.

obsolete (end-of-service-life). A material becomes obsolete when it no longer provides the desired services or when other services are valued more than those provided by the material in question.

old scrap. Scrap including (but not limited to) metal articles that have been discarded after serving a useful purpose. Typical examples of old titanium metal scrap are obsolete airframes, engine turbine blades, and chemical processing tanks. This is also referred to as postconsumer scrap and may originate from industry or the general public.

old scrap exports. The amount of old scrap exported from the United States in a subject year.

old scrap generated. The metal content of obsolete products from the U.S. product reservoir that theoretically becomes available for recycling in a subject year.

old scrap imports. The amount of old scrap imported to the United States in a subject year. old scrap recovered and used. Equals old scrap reported as recovered. Also equals old scrap generated less old scrap unaccounted for less old scrap deposited in landfills.

old scrap recycling efficiency. The amount of old scrap recovered and reused relative to the amount available to be recovered and reused. Defined as consumption of old scrap (COS) plus exports of old scrap (OSE) divided by old scrap generated (OSG) plus imports of old scrap (OSI) plus a decrease in old scrap stocks (OSS) or minus an increase in old scrap stocks, measured in weight and expressed as a percentage:

$\frac{\text { COS + OSE }}{\text { OSG + OSI + decrease in OSS or - increase in OSS }} \times 100$.

old scrap unrecovered. Scrap that might have been abandoned in place (hibernating), collected and landfilled, or dissipated during use. It is the difference between theoretical scrap generated and actual scrap collected and processed for sale to the global pool of manufacturers.

product reservoir. The stock of titanium-bearing materials serving consumer needs. When materials within the product reservoir reach their end of life (meaning end of utility), they become eligible for utility upgrade, one method of which is recycling as old scrap.

recoverable titanium. The flows reported here are for recoverable titanium, that is, in terms of the titanium contained in products. There are dissipative losses to air water and land throughout the system, but these are not quantified. This approach makes the system appear to balance, but the reality is that more titanium (to cover the dissipative losses) than is reported is required to produce the product reported.

recycling. A process to reclaim a metal (titanium) in a usable form from scrap or wastes. This includes recovery as the refined metal or as alloys, compounds, or mixtures that are useful. Examples of recycling are recovery of titanium from titanium-bearing alloys, such as Ti-6Al$6 \mathrm{~V}-2 \mathrm{Sn}$.

recycling rate. The fraction of the apparent metal supply that is scrap on an annual basis. It is defined as consumption of old scrap (COS) plus consumption of new scrap (CNS) divided by apparent supply (AS), measured in weight and expressed as a percentage:

$$
\frac{\mathrm{COS}+\mathrm{CNS}}{\mathrm{AS}} \times 100 \text {. }
$$

scrap consumption. Scrap added to the production flow of a metal or metal product.

supply of recoverable titanium. The sum of new (prompt) scrap, old scrap recovered, old scrap imports, and old scrap stock decrease. This supply serves the domestic and foreign demand for scrap. 
swarf. A conglomerate of fine metallic particles, chippings, and shavings removed by cutting and (or) grinding tools. Swarf may contain a residue of cutting oil, which is generally removed prior to recycling .

titanium-containing assemblies. Products that contain multiple materials only some of which contain titanium. An aircraft is an example. The titanium-containing portions might include a spar in the airframe and turbine blades in an aircraft's engine. When the United States imports assemblies, the distribution of the content of these materials is frequently unknown. volatility. A system that generates data (in this report, for the titanium market) can be statistically described by common statistical parameters, such as the mean and the variance abut the mean. In general, systems that generate point distributions with variances of more than 20 percent (as the titanium market system does) can be described as highly volatile. Such a system likely will show supply and demand mismatches at various moments in time, and these likelt will generate wide price variance from moment to moment. 